\title{
PENGARUH EKSTRAK KULIT BATANG JAMBU METE (Anacardium occidentale Linn.) SEBAGAI BAHAN ANTISEPTIK TERHADAP EKSPRESI VASCULAR ENDOTHELIAL GROWTH FACTOR (VEGF) PADA LUKA BEKAS PENCABUTAN GIGI MARMUT
}

\author{
(INFLUENCE OF CASHEW STEM BARK EXTRACT (Anacardium \\ occidentale Linn.) AS AN ANTISEPTIC ON VEGF EXPRESSION \\ AFTER TOOTH EXTRACTION OF THE GUINEA PIG)
}

\author{
Harsini*, Iwa Sutardjo**, Sudibyo Martono***, Siti Sunarintyas*, Sudarsono**** \\ *Departemen Ilmu Biomaterial Kedokteran Gigi \\ **Departemen Ilmu Kedokteran Gigi Anak \\ Fakultas Kedokteran Gigi, Universitas Gadjah Mada \\ Jl. Denta, Sekip Utara Yogyakarta 55281 \\ ***Departemen Kimia Analitik \\ ****Departemen Biologi Farmasi \\ Fakultas Farmasi, Universitas Gadjah Mada \\ Jl. Sekip Utara Yogyakarta 552956
}

\begin{abstract}
Tooth extraction causes a disorder of tissue continuity which requires time for healing. Vascular Endothelial Growth Factor (VEGF) is one of the many pro inflammation mediators that related with new blood vessel formation. Cashew stem bark (Anacardium occidentale Linn.) has phenolic compound that controls cell function by inducing VEGF. The aim of this research was to know influence of cashew stem bark as an antiseptic on VEGF for the guinea pig tooth extraction scar. The research used cashew stem bark from Mojolegi, Karangtengah, Imogiri, Bantul. Extraction was done by maceration with $70 \%$ ethanol. After we obtained a thick extract, an antiseptic was made in different concentrations; namely 3, 5, and 7\% and aquadest as control. Fourty eigh guinea pigs, male, aged 2,5 to 3 months and weight 250-300 g, were divided into 3 groups and one group as control, each group consisted of 12 guinea pigs. All of their lower incisives were pulled out. The aquadest were given to the first group as control, the 3\% concentrations of antiseptic were given to the second group, $5 \%$ concentrations were given to the third group, and $7 \%$ for the fourth group. Four Guinea Pigs from each group were then decapitated after 3, 7, and 14 days. The tissues were taken and being made into histological specimens by immuno histochemistry staining to count VEGF expression. Data was analyzed by two-way Anova and followed by $\mathrm{LSD}_{0,05}$. The results showed that the variation among concentrations, number of days, and interactions of concentration and day provided effects to VEGF expression $(\mathrm{p}<0.05)$. By LSD test, it was known that there were significant effects on VEGF expression between the concentration and number of days. In conclusion, an antiseptic of Anacardium occidentale stem bark extract influences VEGF expression.
\end{abstract}

Key words: Anacardium occidentale Linn, phenolic, VEGF

\begin{abstract}
Abstrak
Pencabutan gigi dapat berdampak pada penghambatan kontinuitas jaringan yang memerlukan waktu untuk kembali sembuh. Vascular Endhotelial Growth Factor (VEGF) merupakan salah satu mediator pro inflamasi yang berhubungan dengan pembentukkan pembuluh darah baru. Kulit batang jambu mete (Anacardium occidentale Linn.) mempunyai kandungan fenolik yang dapat berperan pada pengaturan fungsi sel dengan menginduksi VEGF. Penelitian ini bertujuan untuk mengetahui pengaruh konsentrasi ekstrak kulit batang jambu mete sebagai bahan antiseptik terhadap ekspresi VEGF pada luka dampak pencabutan gigi hewan coba (marmut/Guinea Pig). Kulit batang jambu mete diambil dari Mojolegi, Karangtengah, Imogri, Bantul. Ekstraksi dilakukan secara maserasi dengan pelarut etanol 70\%. Bahan antiseptik dibuat dalam konsentrasi 3\%, 5\% dan
\end{abstract}


7\%. Sebanyak 48 ekor marmut jantan, umur sekitar 2,5-3 bulan dengan bobot badan rata-rata 250-300 gr dibagi menjadi 4 kelompok dan setiap kelompok terdiri atas 12 ekor. Seluruh marmut dilakukan pencabutan gigi insisivus bawah kanan. Kelompok I adalah kelompok kontrol yang ditetesi air suling. Kelompok II ditetesi ekstrak kulit batang jambu mete dengan konsentrasi 3\%. Kelompok III ditetesi ekstrak kulit batang jambu mete 5\% dan kelompok IV ditetesi ekstrak kulit batang jambu mete 7\%. Dekapitasi tiap kelompok sebanyak 4 ekor dilakukan pada hari ke 3, 7dan 14. Setelah dekapitasi, soket bekas gigi diambil dan dibuat preparat histologisnya dengan pengecatan imunohistokimia. Penghitungan ekspresi VEGF dilakukan dibawah mikroskop dengan perbesaran 40x. Data yang diperoleh dianalisis menggunakan Analisis Varians dua jalan dilanjutkan dengan $L S D_{0,05}$. Hasil penelitian menunjukkan antar konsentrasi, antar hari, dan interaksi antar konsentrasi dan hari berpengaruh signifikan terhadap ekspresi VEGF $(p<0,05)$. Pada uji LSD diketahui terdapat perbedaan ekspresi VEGF yang signifikan antar kelompok konsentrasi dan kelompok hari. Sebagai kesimpulan, ekstrak kulit batang jambu mete dalam bahan kumur berpengaruh terhadap ekspresi VEGF.

Kata kunci: Anacardium occidentale Linn., fenolik, VEGF 